Article

\title{
Sustainable Family Farming Futures: Exploring the Challenges of Family Farm Decision Making through an Emotional Lens of 'Belonging'
}

\author{
Lorraine A. Holloway ${ }^{1, *}$, Gemma Catney ${ }^{1}\left(\right.$, Aileen Stockdale ${ }^{2,+}$ and Roy Nelson ${ }^{3}$ \\ 1 Geography, School of Natural and Built Environment, Queen's University Belfast, Belfast BT7 1NN, UK; \\ g.catney@qub.ac.uk \\ 2 Planning, School of Natural and Built Environment, Queen's University Belfast, Belfast BT7 1NN, UK \\ 3 School of Biological Sciences, Queen's University Belfast, Belfast BT7 1NN, UK; r.nelson@qub.ac.uk \\ * Correspondence: 1holloway02@qub.ac.uk \\ † Deceased 27 March 2021.
}

check for

updates

Citation: Holloway, L.A.; Catney, G.; Stockdale, A.; Nelson, R. Sustainable Family Farming Futures: Exploring the Challenges of Family Farm Decision Making through an Emotional Lens of 'Belonging'. Sustainability 2021, 13, 12271. https://doi.org/10.3390/ su132112271

Academic Editor: John McDonagh

Received: 28 September 2021

Accepted: 2 November 2021

Published: 6 November 2021

Publisher's Note: MDPI stays neutral with regard to jurisdictional claims in published maps and institutional affiliations.

Copyright: (c) 2021 by the authors. Licensee MDPI, Basel, Switzerland. This article is an open access article distributed under the terms and conditions of the Creative Commons Attribution (CC BY) license (https:// creativecommons.org/licenses/by/ $4.0 /)$.

\begin{abstract}
This paper illustrates the importance of moving beyond an economic focus, and towards an emotional one, to gain a more comprehensive understanding of why farmers can be reluctant to retire and/or pass their farm onto the next generation. We report on a two-phase qualitative study of family farm decision-making processes in Northern Ireland, drawing on 62 in-depth oral life history interviews with farmers, farmers' spouses, and farm successors. In an attempt to gain a deeper understanding of the emotional aspects of retirement and succession decision-making processes, and their relationship with place belonging, in the first phase of this research we employed an innovative 'Work and Talk' method, whereby interviews were conducted while shadowing, or in some cases, co-working, with farmers on their land. The second phase of this research responded to restrictions arising from the COVID-19 pandemic, and involved remote telephone or online interviews with family farm members. This research revealed the complex relationships between a 'longing for belonging' and emotional attachment to the family farm, and the challenges associated with patrilineal farming structures, expectations and identities, in planning for succession. The emotional impacts of strained relationships with policy makers around support for retirement emerged as a surprisingly dominant theme throughout the interview process, suggesting the need for greater emphasis on the emotional aspects of farming retirement and succession planning to inform future rural development policies targeted towards the sustainability of family farms.
\end{abstract}

Keywords: family farm; ageing farmers; retirement; succession; emotions; decision making; belonging; respect; rural sustainability; Northern Ireland

\section{Introduction}

There are over 500 million farms across the Global North and South, which are mostly managed by farm families [1]. The EU and the UK are reliant on family farming for economic sustainability, where in Northern Ireland (NI) the family farm and the agri-food industry plays a more significant economic role than in the rest of the UK [2]. Yet, family farming in NI offers more than just economic advantages; it is commonly viewed as the 'heart of rural communities' [3] because of its positively perceived values, its endurance over time and between generations, and its cultural assets [4].

The family farm, and, more broadly, rural communities have transformed over the last 100 years due to technological advances, globalisation and demographic changes, where government intervention and EU policies have, in part, been successful, for example in improving quality of rural life and supporting farm income [5]. However, in NI, where family farming remains patrilineal, a recent survey by the Ulster Farmers' Union highlighted that there are persistent policy shortcomings concerning ageing farmers, particularly in relation to retirement decision making and issues of rural belonging [6]. 
To date, the agricultural and rural literatures have focused on farmers' economic 'roots' to place, yet there is less research on how modern rural communities can affect the emotional, temporal and spatial connection to place amongst farmers, such as attachment to the land or farm animals. Research in Australia has identified that a loss of a 'sense of belonging' can impact not only on farm decision making but also the health and well-being of farming families [7]. The economic focus of the effects of rural change on farmers' decision making fails to understand the emotional dynamics behind why farmers can be reluctant to let go of the family farm. As argued by Errington and Gasson, family farm members' emotional attachments to place can often supersede rational or economic judgements within the decision-making process [8].

This paper aims to utilise an emotional, rather than an economic, approach, to investigate how a 'sense of belonging' within changing rural communities can shape family farm retirement and succession decision-making processes in Northern Ireland. In recognition of the need for greater understandings of the effects of farmers' emotions [9], this research explores how farmers' embodied feelings (physical and emotional) alongside their experiences (memories) of belonging can affect their perceptions of, and anxieties around, retirement and succession. This research considers the family farm as both a 'place to belong' and a 'sense of belonging' [10]. The paper draws on interviews with 62 people across small livestock farms in Northern Ireland, with 21 farming men, 20 women spouses of farmers, and 21 adult children of farmers, of which all but one were successors. An innovative Work and Talk methodology was applied in an attempt for the interviewer to dig deeper in conversations with farming families. These involved, for example, shadowing and assisting participants on the farm or in the family home. Northern Ireland is an interesting case study in which to understand these patrilineal embodied emotions based on its agricultural reliance and emotive historical land ownership.

\subsection{Emotions, the Family Farm and Decision Making}

Emotions are a part of our human experience and they are not only essential to helping us describe the world around us, but also help us shape what we think of it and how we want to respond to it [11]. Emotions are difficult to define; however, in simple terms, they might be ultimately understood as our feelings and how we react to positive or negative situations, which are also 'corporeal', permitting us to comprehend how we feel and think [12]. Emotions, however, are not inherent; they can be acquired $[9,13]$. Anderson and Smith's much cited editorial explores the links between places, spaces and emotional experiences [14]. Paying attention to emotion in our research allows us to appreciate how people's lives are lived and experienced, and in turn how emotions affect their environment based on emotional bonds formed, which also shape one's sense of identity [14]. An example of this raw embodiment of thinking and feeling is illustrated in Pini et al.'s study of a coal mine closure in rural Australia, which demonstrates emotional loss through the feelings of betrayal, anger and resentment to the closure of the mine that dominate over any economic loss [15].

There is still much to learn from understanding the emotions of farmers and their families within changing rural communities. Notable exceptions include Ramirez-Ferrero's book 'Troubled Fields', which demonstrates that it is not just economic issues affecting the mortality rate of farming men in a time of crisis, but social and cultural issues because of rural modernisation [16]. Price and Conn's research on keeping the name on the land in Northern Ireland also identifies that succession is an emotional process, rather than a practical one [17]. Rieple and Snijdger's work recognises the need to understand the 'emotional dimensions' of family farm decision making; in their case, within traditional farming structures [9]. Undertaking semi-structured interviews with 27 dairy farmers in Munster (Republic of Ireland; RoI), Rieple and Snijdger explored emotions to innovation on the farm, concluding that decision making is based on various emotional factors, such as satisfaction with a traditional farming 'lifestyle', socio-emotional bonds within communities, safeguarding the continuity of the family farm, and a preference for traditional, 
rather than economic, decision making to cattle selection [9]. Conway et al.'s research in the RoI illustrates further that emotional issues, such as loss of farming identity, status, power and the relationship with the farm, especially in later life, are affecting older farmers' retirement decision making [18,19]. Their paper also argues that more evidence is needed to understand emotional attachment to the farm and its 'embodied contents', such as livestock, land, and the farm. Glover and Reay's study on dairy farms focuses on the non-financial socio-emotional wealth of farmers, illustrating that in order to encourage future farm sustainability, policy makers need to be aware that, regardless of any economic issues on the farm, the value, goals and emotional attachment of the farm family are key to farm survival, and that this is evidenced even by farmers without a successor [20]. As Grubbstrom and Erickson's research on retired farmers' decision making in Sweden illustrates, it is emotional incentives such as intrinsic values, care for the environment, land and rural community which entice them to either sell or lease their property to the next generation [21].

Place attachment(s) is important when trying to understand emotions on the family farm because it is argued that the more time spent in place, the greater the emotional attachment to place [22]. This is especially evident for older people who might naturally have spent a longer length of time in one place, building relationships, memories and bonds [23]. Yet, while elective belonging in urban space has received scholarly attention [24], there is a need for better understandings of belonging or elective belonging in rural areas, as proposed by Stockdale et al. (2018) [25]. Erickson et al.'s paper on rural stayers argues that research is still lacking on the importance of place and how it can enhance qualities such as community attachment, rootedness and a sense of belonging [26]. Stockdale and Ferguson's research in NI suggests that stayers in rural areas demonstrate a strong sense of place attachment and belonging, but that these are intertwined with complicated relationships with family history, farm ownership and continued family networks [27]. This emotional place attachment of 'being at home' is heightened further when relied on for 'survival' [28], such as farms, which have a clear socio-economic role.

\subsection{The Emotion of Belonging}

It is widely accepted that people share a desire to 'belong', and to have a sense of attachment $[29,30]$. However, it is only relatively recently that belonging within rural communities has been the subject of academic attention [31]. Belonging is multidimensional and can mean many things; it can refer to a place, identity, thoughts, and our emotions and feelings, which can have a direct reflection on our personal experience of belonging $[10,14,29]$. Allen et al., in defining belonging, argue that a need to "connect deeply with other people" is a common factor, but that direct involvement is not always necessary in order to connect, and instead can be based on the quality, experiences and observations of these connections [32] (p. 88). Others will gain on a 'sense of belonging' through their social connections, for example, through their childhood experiences, and place where they grew up [33].

To put this relative to family farming, and in particular to farming retirement and succession, because farms are commonly passed down through the generations, they offer a treasure chest of social and familial inter-relations and experiences that can impact on family members' sense of belonging [34]. For example, Price and Evans, in their case study of rural mid-Wales [35], identify the evolving relationship with farming women. Price and Evans reveal how, unless women were from a traditional farming background, they were often considered by farming men as a threat to the success and survival of the family farm, in respect to issues around marital breakdown and inheritance, ultimately affecting succession planning. Price and Evans also discuss how the complex patrilineal culture means that farming men tend to only seek emotional help from those that are from a common background, or farming 'way of life', and as rural communities change, this support culture is becoming at risk [35]. Yet, it is not just the inter-relationships between people, belonging and retirement decision making. Riley, for example, explores the roles 
of farmers' livestock in shaping farmers' identity and attachment, arguing that "animals are central to the everyday lives and identities of farmers ... separation from them alters farmers' attachment to particular practices, places and social networks" [36] (p. 2).

Place attachment- to the farm and farmland - forged as it may through relationships with family, community, animals, and through inheritance, history and memory, is a central aspect of farmers' identity and belonging. Riley identifies the importance of, and opportunities presented by, making 'place' central within the research process as it provides important insights into farming identities, emotions and social relationships [37]. An example of this is the traditional patrilineal farming structure, which provides a farmer with a sense of (place) identity, and one farmers can be reluctant to let go of, especially in retirement. Bryant and Pini noted that a sense of belonging and age are interlinked in rural communities, especially with older farming men, as seen through their 'pride of place', developed through the generations of family land ownership [31] (p. 136). Price and Conn identify this in their study by exploring the continuing reliance of the patrilineal requirement to keep the name on the land; they show how place attachment through the 'pull of the land' has a significant influence on succession planning in NI [17]. Price and Evans's ethnographic case study of farm families in Wales identified that attachment to a farming 'way of life', experienced through farming identity, relations, roles, and home, can contribute and/or cause farming 'distress' [35].

Our research objective is to gain a better understanding of the emotion of belonging in family farming, and how this influences the retirement decision-making processes. It might be argued that without this awareness, current rural development policies are paying insufficient attention to the importance of traditional patrilineal farming identities within changing rural communities, and the unique challenges experienced by farmers faced with losing, or at least weakening, their farming identity and place belonging, as they transition to retirement.

\section{Northern Ireland Context}

The family farm and the agri-food industry play a more significant economic role in Northern Ireland (NI) than in the rest of the UK, with an annual turnover overall of $£ 4.5 \mathrm{bn}$ each year from over 24,827 active farms [38]. Approximately $75 \%$ of the total land area in NI (1.35 m hectares) is agricultural, albeit with a decline by 1\% since 2019 [39]. Most farms in NI today are classed as 'very small' $(76 \%)$, operated by families and supported by family labour with a reliance on the patrilineal family farm structure. Price and Conn's mixed methods research examining the prerequisites of 'keeping the name on the land' demonstrated the possibilities offered by an NI case study for understanding patrilineal retirement and succession decision making [17].

NI's agricultural space can be considered unique compared with the rest of the UK because of its shared border with an EU State through the RoI [40]. Economically, DEFRA has also identified an inadequate acknowledgment of the essential differences between the agricultural sector of NI and other parts of the UK [41]. Price and Simpson argue that it is important for legislation to acknowledge NI's 'otherness' to the rest of the UK because of its agricultural dependence and region-specific characteristics [42]. Indeed, NI's historic struggles with land ownership via political conflict represents a key difference to the rest of the UK [42], and land in NI, much like the RoI, is very much a part of NI's rural culture. Land, of course, is an asset and vital for most rural economies for growth in part, but for NI (and RoI), there is link between land and identity where it has acted to control belonging at micro levels and divide communities at macro levels [42]. Land in NI is also linked to freedom of land ownership, a unique land tenure system which defines how property rights are allocated, transferred, and used [43,44]. In relation to farming in NI, this includes a 'fee farm grant' which is comparable to that of a freehold title where land can be leased indefinitely and sold on in the same basis through the family to secure the title of land ownership for the tenant [43]. 
In short, NI's uniqueness, through its patrilineal agricultural reliance, culturallymotivated emotive relationship with land ownership, and land protection through its legislation [42], makes it an interesting case study to explore the emotional decision making of patrilineal farmers and their families.

\section{Methodology}

This research, undertaken on the family farm, intends to elucidate how farmers' embodied (physical and emotional) feelings alongside their experiences (such as memories) of belonging can shape their retirement and succession decision making. A Constructivist Grounded Theory approach was deemed appropriate for this research as it can be rewarding for studies where very little theory exists [45-47]. The collected data were reviewed as an ongoing process throughout the analytical phase, in order to allow core concepts around themes to emerge [45].

\subsection{Research Sample}

Several factors influenced the semi-structured interview sampling strategy. Farmers aged 50+ are most likely to be in the process of making retirement or succession decisions. In Northern Ireland, the average age of the farmer is 58 , with only $6 \%$ of farmers under the age of 35 [48]. We therefore aimed to recruit farmers and successors between the ages of 18 and 75, with most farmers aged 50 and over. The agricultural literature suggests that research samples should also be led by farm size [49]. The average farm size and type in Northern Ireland is small/very small and livestock based [50], and the sample reflected this.

As illustrated by Errington and Gasson, you cannot fully understand the family farm structure without understanding the family relationships that manage it [8]. The roles of family farm members, and the relationships between them, can also heavily influence and/or aid family farm decision making [51]. Yet, women's roles in the decision-making process are often underestimated, despite their significance [52,53]. Chiswell also argues that while it is essential to understand the intergenerational process, it is also imperative to recognise the successor and who they are, as valuable actors in the retirement and succession process [54]. In some cases, there are family members who also want to farm but cannot, given that their sibling is first choice (generally because they are older). In this case, the '(non-)successors' are also important research participants, as their role is often undervalued within family farm continuity processes [55]. To respond to the significance of these different family roles, the fieldwork targeted the recruitment of farmers, farmers spouses, successors, and (non)-successors for the in-depth interviews.

The final purposive sample was 62 participants, with 21 farmers aged 33+, 20 women aged 21+ married to farmers, 20 successors and one (non-)successor aged 18+, from 20 small/very small farms with livestock across NI. One-quarter of the participants interviewed were from the same families (e.g., a farmer, their spouse, their successor (adult) child). The other participants were independent family farm interviewees. All but two farmers were men, all spouses were women, all but two successors were men, and the (non-)successor was a woman. Out of the 62 farm participants interviewed, 53 were educated to technical or third-level college, with the remaining nine educated to the primary or secondary level (each of which were aged over 60 years).

The interviewees are assigned labels as illustrated in Table 1. In the discussion of the interviews, after each label (e.g., Farmer, Spouse), a number is included which reflects the order in which the participants were interviewed (i.e., Famer 1, Spouse 1, etc.). Given the dominance of men in the sample of farmers and successors, gender labels are only provided if the farmer or successor was a woman. 
Table 1. Farming Participants by Cohort.

\begin{tabular}{ccc}
\hline Farmer, aged 18-49 & Spouse, aged 18-49 & $\begin{array}{c}\text { Successor, aged 18-29 } \\
\text { Successor, aged 30+ } \\
\text { Farmer, aged 50+ }\end{array}$ \\
Spouse, aged 50+ & (Non-)Successor, aged 18-29 \\
\hline
\end{tabular}

Adopting a Grounded Theory approach $[45,47]$, this research began with a sample of farming participants (farmer/spouse/successor/(non-)successor) who were identified and selected by the lead researcher by attending various farming events across NI. These events, and the interviewees who were recruited from them, allowed for a snowballing process to further inform, and in turn recruit, additional farming participants. While this simple referral system can have some disadvantages such as selection bias, these were outweighed by the opportunity to reach potential participants who would otherwise be difficult to establish contact with [56]. The initial sample of interviews allowed for the identification of emerging themes through an iterative process of interview data analysis until 'data saturation' occurred $[45,46]$. The priority of this research was to give farming participants a voice, in order to articulate and, in turn, better understand the emotional perceptions of decision making within changing rural communities. The methodology underwent ethical approval and interviews which were conducted from October 2019 to March 2020, through two phases.

\subsection{Fieldwork Methodologies}

\subsection{1. 'Work and Talk' Interviews}

The first research phase involved 21 oral life history 'Work and Talk' semi-structured interviews, which were conducted from late October 2019 until March 2020. The interviews were used to explore the participants' biographies, where interviewees could recall and reflect on their experiences in their own words, aiming to "move away from well-rehearsed, amusing anecdotes to a deeper exploration of subjectivity" [57] (p. 5). It has been suggested that this articulation of personal 'life stories' can prove a useful technique to encourage participants, and in particular older men, to open-up about their individual personal experiences [58,59].

The innovative 'Walking and Talking' methodology of Anderson (2004) is a popular tool in qualitative rural research [60] (as examples, see Riley) [61-64]. A fusion between interviews and 'hands-on' observation, this approach has grown in popularity for exploring themes related to the relationships between self, space and attachment, and usually takes place in an area relevant/related to the research [65]. As an example, Riley's study on changing agricultural practices adopted a Walk and Talk approach, and provided the interviewer with access to 'hidden voices' on the farm, as well as allowing for a flexible approach in order to fit into the everyday commitments of the respondents [66]. The embodiment of walking also had the added benefit of centring 'place' in the research; as Riley, notes, "The farm is a site of knowledge construction, and understandings may be embedded within, and layered on its fields and practices" [66] (p. 662).

Inspired by the benefits of this Walk and Talk method, a novel participatory approach was developed for this research: 'Work and Talk'. The lead researcher became immersed in the everyday life of the farm by working whilst interviewing. This involved, for example, shadowing and assisting each participant either on the farm or the family home by doing menial tasks such as brushing the yard, mucking out, or helping in the kitchen.

The Work and Talk approach proved productive in several key ways. As with the Walk and Talk method, it provided a flexibility with the interview process that allowed the interviewer to respond to the participants' working commitments on site. Farmers felt more able to agree to be interviewed, since the process was less distracting from their working day. The approach also unveiled 'hidden voices', where participants were free from judgement (see Riley [66]), as illustrated by Farmer 6 (aged 50+), when discussing issues around farm aspirations and retirement which he was reluctant to discuss as a couple earlier in the interview: "I can say that now ... sure she would say the opposite! [laughter; 
indicating to the farmer's spouse in the distance]" ... As the lead researcher (who also conducted the interviews) is not from a farming background, there was initial concern over potential problems in gaining access to family farm participants, given negative perceptions of their 'outsider' status. As an example, Farmer 11 (aged 50+) remarked, while indicating to the researcher's attire, "well you're not from farming anyway". Kuehne argued that it is important, when interviewing farmers, that the interviewer should try to 'fit in', and demonstrate their interest in the farming way of life, to encourage a good rapport [67]. Offering to conduct the interview while helping with basic farm tasks through this 'Work and Talk' process immediately softened any distrust or indifference towards the interviewer. The approach enabled the interviewer to earn respect by 'getting stuck in'. This not only gained the researcher access past the elusive farm gate, but also helped with further research sampling.

The embodiment of Working and Talking on the farm also gave insight to the relationships between the participants' life stages, across time but also place. It encouraged participants to open-up and reveal more of their biographies, exploring and reflecting on the physical family farm. Younger successors also engaged with this remembering and reflective process, where working and talking gave them a chance to 'show off' the farm, often illuminating a great sense of pride, especially if the farm had undergone improvements, such as the introduction of new milking equipment. This biographical participatory method, being undertaken physically on the farm, was also often viewed as a welcome excuse to stop and reminisce, especially for older farmers and their spouses. This was even more acute at the kitchen table, which also gave the interviewer insight into relationships and in particular power dynamics within the family, especially between the farmer and their spouse. It was through the natural flow of finishing work and walking to the home, within their safe space and surrounded by generations of family memorabilia, that the participants were more animated and emotional, encouraging a deeper exploration of the research themes. Some farmers would emotionally and wistfully recall their mother baking bread, or making stews for all who entered the house, especially when farm advisors were regular visitors. There were also happy, sad, or difficult emotional recollections of the farm while moving between sites, as discussed, for example, by Farmer 4 (aged 50+) "I have no one to take over; [crying] my daughter has no interest in the farm and what do I do, I don't want to leave, look [indicating to a photo of the generations of family on the farm]."

Each interview lasted one to three hours, and was audio recorded with permission and transcribed soon after the interview took place. Themes of belonging and rural community change are at the roots of this research, and questions were loosely asked around participants' perceptions of embodiment (space, place, attachment) to their farm decision making across their lifetime. Farming participants were not asked if they felt like they 'belong' to rural communities, but rather what 'belonging' on the farm and rural communities has meant to them, in their occupation and identity as farmers, and how belonging within changing rural communities may have affected their retirement and succession decision making. For example, participants were asked about their farming identity, and if and how it had changed within their lifetime. They were asked to reflect on the emotional aspects of family farm retirement, as well as questions related to family farming and community. A sample of the interview question guide can be found in Appendix A.

The use of the oral life history Work and Talk method greatly suited the emotional focus of this research, especially with the older farmer and women participants, as it helped guide them through any emotional past experiences that connected to the present. For example, one farmer was visibly upset in the interview when recalling how he had been asked by his spouse to knock down some farm sheds (due to aesthetic reasons) near the family home. Due to the generations of family and community 'ceilidh' dances that had been held there, the farmer was reluctant to destroy the buildings, and it was causing much conflict within the family. In this case, as with others, the interconnectedness between the farmer's physical and emotional attachment to the farm was revealed. 


\subsubsection{Online and Telephone Oral Life History Interviews}

In March 2020, the initial first phase of the Work and Talk research was adapted due to COVID-19 limitations to protect the interviewer and research participants [68]. The second phase of the research fieldwork thus continued with the remaining 41 farming participants using oral life history online/telephone interviews, which took place from July 2020 until December 2020. Thirty of these remote interviews were conducted on the telephone using chat software with the remaining farmers and spouses. One farming couple took part in the telephone interview together, while the rest were individual. Reflecting differences in technological preferences/confidence between generations, the rest of the remote interviews were conducted with successors aged 18-29 using video conference technology.

Despite the advantages of the Work and Talk approach, there were some limitations, such as family members interrupting interviews, or distractions given participants' workloads on the farm. Additionally, unless successors had taken over the farm completely, or were heavily involved, the 'Work and Talk' approach was less appropriate for this group. Moving from face-to-face to a combination of online and telephone interviews helped with this issue; successors generally preferred the freedom to talk on their smartphones. This approach also provided successors with the opportunity to share and reflect on photos [69] of their farm, ensuring that place remained central to the conversations, despite the interviewer no longer being on site. As an example, Successor 7 (aged 30+) had inherited the farm from her uncle, and to facilitate a discussion of her farming passion through her life course, she shared images of childhood memories on the farm. The second phase also proved especially effective when discussing sensitive topics; telephone interviews can, for example, reduce stress in emotionally charged situations, allowing more freedom to disclose information because of the lack of visual representation [70]. As an example, Spouse 8 (aged 50+) admitted at the end of the interview that she had found it easier to talk to a stranger on the phone than she might have in person about their family conflict following her son's marriage breakdown. While this loss of visual interaction can be disadvantageous [70], a mixture of telephone and online interviews proved effective for reaching a diversity of participants. Remote interviews also allowed for flexibility in terms of when the interviews could take place, and their duration [71]. Some spouses preferred to take part in the interview late in the evening when they 'had time to relax', or their formal workload was complete. However, and importantly, participants now also had a choice of where the interview took place, enabling greater privacy, without other family farm members nearby. This tended to aid a more open conversation about the emotional aspects family farm relationships affecting family farm decision making.

\subsection{Analysis}

All semi-structured interviews were transcribed verbatim after each interview, and each transcript was then open line coded manually, by exploring recurring themes across the transcripts. Transcripts were then re-read, and axial coded through an iterative process, identifying relationships between the categories until theoretical saturation was reached [45]. These themes were then explored, informed by the work of Ajzen, Allen and Kern as well as that of Antonisch, Fenster and Yuvas-Duval, and Debeauvoir, as illustrated in Table $2[10,30,72-74]$.

The transcripts were then also analysed by cohort of farmer, spouse, successor and (non-)successor, to compare emotional perceptions of belonging and decision making between the groups. Memo-writing, undertaken throughout the interview process in addition to the recording, helped to clarify any connections between codes and categories based on participants' body language, emotions, feelings, demeanour, etc. 
Table 2. Research Conceptualisation: Emotions and Family Farming over the Life Course.

\begin{tabular}{ll}
\hline Unresolved or unrecognised emotions & $\begin{array}{l}\text { To signal any habits or policies that require attention } \\
\text { through changing rural communities or a changing } \\
\text { family farm structure and have been excluded to date. }\end{array}$ \\
\hline Farmers' Planned Behaviour & $\begin{array}{l}\text { The traditional patriarchal structure, what is considered } \\
\text { 'normal' by farmers and peers, their attitudes, intentions, } \\
\text { beliefs and/or how easy it is to implement or take } \\
\text { control over their decision making. }\end{array}$ \\
\hline Emotional Sense of Belonging & $\begin{array}{l}\text { Participants' emotions towards social bonds and the } \\
\text { desire to connect, attachment to groups or people } \\
\text { (including through childhood experiences), perceived } \\
\text { quality of those social bonds. }\end{array}$ \\
\hline Emotional Place Belonging & $\begin{array}{l}\text { A sense of security that is built through a feeling of } \\
\text { 'home' through participants' oral life history, social } \\
\text { connections, cultural, economic and } \\
\text { environmental factors. }\end{array}$ \\
\hline
\end{tabular}

The fieldwork was conducted in the uncertain times of Brexit and the global pandemic; however, the emotional focus of this research was notably welcomed by the interviewees. Once the farm gate was (literally and metaphorically) opened, most of the participants were eager to share their views and emotional experiences of family farming, often reflecting on the process as cathartic during what were difficult times for farmers and their families. There were even expressions of gratitude that this research was being undertaken, as illustrated by Farmer 1 and Spouse 1, who remarked "it's good you are asking, this is great, this should've been done more before"; "you think no one cares".

\section{Results}

The following sections explore the core themes which emerged from the in-depth interviews: the changing patrilineal tradition identified through a 'longing for belonging' by keeping the farm in the family, communication on the family farm in relation to decisionmaking processes, and the emotional impacts of developing policies and relationships with policy makers.

\subsection{A 'Longing for Belonging' to Keep It in the Family}

As noted earlier, Northern Ireland has a unique relationship with issues of land ownership, and this emerged very clearly from the interviews. A passion for the land and the farming 'place' - the family farm and its surrounding rural landscape-emerged clearly from the farmers' narratives. This had a particular resonance with farmers for whom the land had been passed down through familial generations. There was an awareness that farmers felt a sense of security, or a 'feeling of home', through 'place belongingness' [14], by keeping their farm in the family.

Farmer 1, who has two daughters and one son, provides an example of this emotional security. For him, as with other participants, keeping the farm in the family was very important, but his son was not interested in the farm. His spouse, however, was adamant that each of their children would be given an equal share of the farm. Regardless, he still holds on to hope for this strong traditional patrilineal to be maintained, and that his son would eventually change his mind and take over the farm completely, regardless of any conflict with his spouse or daughters:

"It would be a very simple decision if [son] had the interest in the farm and nothing or not really nothing else, but he had a real genuine interest in the farm. I would not be intent of leaving [son] a third of the farm, or half of the farm, or two thirds of the farm, ... he gets the lot" (Farmer 1, aged 50+).

Farming participants' 'sense of belonging' and rootedness to place was evident through the pride shown across generations and the desire to retain the farm in the family. 
However, in some cases, familial conflicts had arisen whereby (potential) successors were less interested in inheriting the farm. Two successors, for example, described the tradition of keeping the family name on the land a 'hindrance', and, while expressing pride in their family's land, reflected on how they were not 'sentimental' about it.

Yet, a passion for family farm tradition was also evident for several of the successors, who felt great comfort from the generations of family ownership on the land. For example, two successors were afraid of losing their farmland, not just physically, but also emotionally. In particular, their emotional relationships with their farmland related to themes of memory, family, inheritance, knowledge transfer, and belonging:

"Is it true, is it really true that I will not get to live here? Because if that is the truth, then you know I may as well just reconcile and let this five-generation thing go ... but it's very, very hard, because even as I sit here, I have memories of being a child, I get great comfort being here and it has helped me with his [uncle] loss" (Successor 8, aged 30+).

"I think it's key to any farm that the family is involved in it, you know, ... anybody can learn how to farm from nature ... but it's from your family you get most stuff" (Successor 19, aged 18-29).

The emotional connections to land, and to farming as a way of life, were expressed throughout the interviews with farmers. In reflecting on his own experience of finding an alternative occupation, one farmer argued that if farming is 'in your blood', it will not go away:

"Well, my parents did everything they could to stop me farming, I was working with an accountancy firm for four years, and then I realised it was the love of farming that brough me back" (Farmer 17, aged 50+).

Yet, despite the desire to maintain the farming tradition, and farm space, in the family, farmers and their spouses commonly explored in the interviews a conflicting push-pull dynamic. The pull of strong emotional attachments to the farm were accompanied by a tension in not wanting to place this traditional burden on their children and the subsequent generations, with some families viewing the farm instead as a 'poisoned chalice':

"I think in some areas there's still a big attraction to keep it in the family, or a responsibility to keep it in the family in certain areas, but I think that's all changing now" (Farmer 7, aged 50+).

"To be completely honest I think it [keeping the family farm] interferes in the family, but my husband would like it" (Spouse 12, aged 50+).

"It's nice, but as I said, I have said to [son] quite openly, if this place isn't working for you and you saw a nice block of land ten, fifty or hundred miles away and you know, move; don't let this history hold you" (Farmer 2, aged 50+).

A complicated relationship between the younger successor and the older traditional farmer also illuminated contrasting views towards the tradition of keeping the name on the land. Successors, when asked about this tradition and their plans for the future of their family farm, used language to describe older farmers as 'set in their ways', and that it is 'their way, or no way'. Farmers' view of the successors to the same question, on the other hand, was of successors having no work ethic or passion for the land. These seemingly strained relationships were causing conflict for some older farmer participants, and illustrated a lost 'sense of belonging' through a lack of confidence in the next generation and being able to pass the farm through traditional intergenerational transfers, as Farmer 4 (aged 50+) described:

"You know, the general hearsay around the country today [is] that farms generally only last three generations in any one family ... the first generation buy the farm and they live in debt for the rest of their lives. The next member of the family takes it over. The next generation-he finishes up any payments and he develops the farm up to what you 
know to be a successful business, and then the third generation comes along and, excuse the phrase, he pisses it up against the wall! [laughs]."

Indeed, some successors were open about not being as passionate about the farm as their predecessors, or keen to work the same long hours. The pull of the emotional attachment of place belonging associated with keeping the name on the land was instead more pragmatic for many successors, where they felt that the accomplishments and sustainability of the family farm today were based on economic choices and not on traditions or legacy [75]. This is well illustrated by the following comment from Successor 7 (aged 18-29):

"... the family name on the farm is very important ... but if it came down the line and you had to move or something... I would like to keep it in the family name, but, you know circumstances with business decisions-you have to make a move ... it wouldn't be the end of the world sort of thing."

However, the patrilineal pressure to keep the name on the land was shared by those successors who had a clear emotional attachment to the farm. In some cases, there was evidence of experiences of stress in keeping the farm going through the family bloodline. Some successors expressed how they felt an incredible responsibility to prevent this loss of family tradition:

"You just wouldn't like to think that the whole thing ends with you-that would be my main fear" (Successor 10, aged 18-29).

"Well, I suppose when you have such a long line of it going back, you sort of feel a bit of responsibility. [Interviewer: is that a lot of pressure?] ... a lot of pressure, but you don't really think about it too much, but when you do there is pressure" (Successor 10, aged 18-29).

The deep interconnections between emotional connectedness to farming and the land, and the emotional pressures of maintaining the family farm, were reflected on in an interview with one successor who tried hard to keep the farm in the family through five generations. Successor 8 had worked on the farm with her uncle for ten years and had nursed him before he died. However, she explained how she quickly felt pressure, intimidation and aggression from her neighbouring uncle and his sons to leave the family farm, given her position as a woman, and a niece, and thus as someone deemed an inappropriate inheritor:

"He [uncle] was in hospital a few weeks later. He talked to me about this [potential problems with family members regarding inheritance] in depth and he said to me, and his last words were, 'I don't think you're going to have peace to live there', and he took a heart attack... [sobbing] and I lost him to that ... and if that wasn't enough, the way we buried him and it was like you know, I feel like I was a pariah in the graveyard and I was really low on the wall and the family were all the way up on the hill looking down [silence]."

And

"In October I was out on the road with a measuring tape getting ready to measure fencing and my [other] uncle swerved the car right at me on the road right for me... I am not kidding you" (Successor 8, female, aged 18-29).

The desires, and pressures, to hold onto the traditional patrilineal line on this 20 acre farm ultimately resulted in much family distress and an ongoing court case. There was evidence with this successor of a loss of emotional security, built by generations on the farm, because they did not conform to the traditional patrilineal family farm inheritance structure.

Along with changing views towards traditional farming, a shift in relation to family farm communication and decision making also emerged from the narratives, as is next explored. 


\subsection{Family, Communication and Farm Decision Making}

One of the core ways in which the emotional aspects of farming retirement and succession decision making were revealed was in the discussions around family communication. Most participants described family conversations in very positive terms, reflecting on how all farm issues were discussed together either at the kitchen table, or on the farm while working. This was discussed by Successor 6 (Female, aged 18-29):

"It's quite simple at home. We all work together: me, Daddy and my sister ... We make decisions together. Daddy involves us heavily in the farm as well. Like, he would ask our opinions ... we all get to make decisions and things like that ... And we all work hard on the farm today. So, at the moment, it's just all three of us pulling together."

It was also agreed by most participants that while the determinants of farming succession had multiple economic dimensions, the emotional aspects of this decision making were also hugely important. These involved discussions with the interviewer around issues such as poor health, anxieties where there was no successor in line, and, more generally, the emotions of retirement planning. Only one-quarter of the participants had any retirement plans or wills put in place. It was evident that this remained a very emotive issue to discuss amongst family farm members (see also UFUNI [6]). Even when there was a will in place, the details of retirement plans were not always shared with, or communicated to, the successor:

"[Interviewer:] Have your Dad and you sat down and talked about succession or retirement plans?

[Participant:] Well, no not directly like ... he has a will and things created and sorted if things go wrong, but there's not an actual sort of time-line as to what will take place like" (Successor 4, aged 30+).

Some older farmers noted the importance of having a will in place, but they felt there was not enough government support or advice to encourage and aid farmers through this emotional process.

The narratives revealed how the most dominant influence on family farm decision making was family farm relationships; an essential element in understanding family farming [76]. This was often strongly linked to themes around perceived threats to the farmers', and in some cases, their spouse's, 'sense of belonging', especially if they were not from a farming background [35]. A prominent example that emerged in these farm relationship discussions, across the three cohorts of farmers, spouses, and successors was the changing views around martial traditions and dissolution. Many of the older interviewees explored issues of stress, anxiety, and fear around the potential for, or in some cases, realisation of marriage breakdowns of successors and how it would impact the future of the farm.

"There's a situation ongoing up the road there; the wife has left the husband after only about three or four years of marriage, and we don't know what way the whole place is going to end up" (Farmer 20, aged 50+).

"My nephew had a marriage that broke down and it was a really dirty breakup ... his father who was a farmer would say that they were very lucky not to have signed over anything or it would all be gone" (Spouse 8, aged 50+).

One farmer and his spouse had experience of the loss of the farm after their son and daughter-in-law separated. They viewed their daughter-in-law as an 'outsider' given her lack of farming background, and consequently placed the blame on her over the marriage breakup and poor communication from their son about the subsequent selling-off of part of the farm:

"[crying] it has broken the family ... none of my daughters talk to him anymore. We don't know what to do now-we thought we could retire. I worry about it all the time" (Spouse and Farmer 7, 8 (joint interview), aged 50+). 
One farmer (aged 50+) coined the phrase the 'dreaded daughter-in-law' to describe these family dynamics, the discussions around which were often highly gendered, and strongly linked to themes of entitlement and (especially when the women were not from a farming background) perceived threats to their place belonging and identity (see also Price and Evans [35]). Several farmers and their spouses reflected on the emotional stress of retirement decision making in the context of these relationships:

"A lot of farmers don't want to hand over their property to their son because of a particular reason. Down the years when my father was living and when I got married marriage was for life, ye know what I am saying! A lot of the things are going belly up at the minute and a lot of farmers would prefer to keep the next generation in line on the farm" (Farmer 10 , aged $50+$ ).

"This is not a judgement comment, but as more and more farmers marry non-farming daughters, that has a big impact as well. Because those ladies don't understand this 80-hour week, week after week, and they shouldn't .. . but, you know, the in-law thing ... if my son said 'I want to work Monday to Friday, you know 50 hours a week, will you do weekends?' I'd think, no I bloody won't!" (Farmer 2, aged 50+).

"My biggest worry is my brother getting married, and, you know, I want to see it, but I don't really have that relationship with his future wife. And I am kind of worried that, you know, you hear of all these farms being sold because of divorces and everything, you know. That's kind of my biggest fear at the minute... If my brother marries, I am dreading it; my sister-in-law is a driving force" (Spouse 18, aged 18-49 (farm is split three ways with brothers)).

Successor 2 (aged 18-29) believed that marriage breakdowns were also related to suicides in farming:

"If they split up in a marriage that's when ... that's when suicides and things come up."

This fear, and lack of trust, was relayed powerfully by one successor, who explained how, at the age of 44 , he did not want the farm signed over to him in case of a future marriage breakdown and potential loss of the farm:

"I really am in no rush for them to sign over the whole farm because there have just been so many incidences with farmers in around my age where the wife has up and left, and it's been a lot of hassle... so I am not given them any pressure on my mother and father to do it, 'cause in two years' time I could be happily married but you never know."

The threat of marriage breakdown was magnified because of the reported lack of legislation in place to protect generations of land ownership. Strong emotional responses to discussions around this issue related to themes of unfairness and frustration, particularly in relation to intergenerational land ownership:

"I think it's wrong, that a wife is able to claim half of the farm ... I could see it happening here ... But anyway, I think that's awful, I think it's dreadful that a man who has built up a farm all his life, his father before has built up the farm, he has handed it over to his son, something has happened, and the wife walks off with half of it. It's not right!" (Spouse 9, aged 50+).

While much of the discussions on communication and relationships focused, unsurprisingly, around the farming family, some farming participants also explored the relationship and role that the animals had on the farm had in yielding a strong sense of belonging. There was an evident connection between the attachment of farm animals to the farm and family [77,78] and 'linked lives', especially with the older farmer [79]. As one farmer reflected:

"[Interviewer:] Are you attached to your livestock?

[Participant:] [cried] I sold two cows recently, and it knocked me for six that they were going to be culled... they were my friends; I work with my friends I didn't want to sell my friends ... it makes me really sad" (Farmer 7, aged 50+). 
The emotional pain felt by older farmer participants when this relationship is lost also affected family farm decision making (see Tovey, 2002) [77]:

"My cows, my children, they all have names ... ahh, yep, the fact the contract fella bought the herd, and they are staying here 'cause I rented the old buildings too ... I didn't have to go through the pain of getting rid of cows; we lost 40 cows almost six years ago to $T B$, and it was like a death in the family for me and my wife" (Farmer 9 aged $50+$ ).

However, the links between emotional attachment to the farm and animals were not held by all, and some expressed indifference to any attachment to animals and its implications for retirement decision making:

"No attachment at all. Sure, you can't-you're not a retirement home for cows you know!

You're a business!" (Farmer 10, aged 50+).

The results indicate that it is essential to consider farmers' relationships with their animals in the farm decision-making processes [78], including their emotional bonds, security and attachment, which are often reinforced daily on the farm. In turn, this showing of compassion for their animals, and being viewed as the 'good farmer', has an important role in shaping farmers' identity [79].

\subsection{The Emotional Impacts of Policy}

Across the three cohorts, there were continued aspirations for the family farm. As examples, some successors planned to enlarge the farm, and to introduce new technology such as solar panels and robotics milking; farmers' spouses often encouraged diversification, and, if from a farming background, managed the economics of the farm; some farmers were hoping to rent out the farm, or contract it to a younger farmer, enabling them to retain the land, but also to retire. Yet, many of these plans were discussed with a heavy heart, with strong feelings that there is little help to achieve them. As Farmer 16 (age 50+) explained:

"I really want to find a young farmer to take over the farm as my girls don't want it.

Someone so I don't have to sell on the herd, and they can just take over, but I can't, and there is no help-I am really stuck."

The interviews involved emotional discussions around feelings of being unsupported. The Department of Agricultural, Environment, and Rural Affairs (DAERA, 2021) is the government body in NI tasked with overseeing food, farming, environmental, fisheries, forestry, and sustainable policies. It also acts as the local managing authority for delivering and evaluating all rural development programs to support growth, jobs, and sustainable development in rural areas [80]. The Department was a core focus of many of the discussions around the perceived lack of farming support, and the emotional burden of feeling unprotected.

"I think a sense of hope, you know, with policy the way that it is at the present time. Yeah, there's a policy of no hope... people feel very vulnerable at the present time; we are being told so many mixed messages" (Farmer 4, aged 18-49).

"We have a department, and we have people now who are making decisions, who are looking at a screen and they have a little block graph and things as to what's best for people. They don't consider the emotional side of things - how things should be done. They just say what's possible legally, and we can do that because as an EU Directive we have to implement this particular law or system: you know, like it or lump it" (Farmer 4, aged 18-49).

A theme of disconnect between farm families and policy makers was evident across the three cohorts, where participants were often animated, upset and angry in interviews, expressing how they felt little respect from the body that had helped them so effectively in the past. Interviewees argued that this had a direct impact on family farm decision making. Poor communication was a recurrent theme, as well as frustration by older farmers and their partners who felt unable to cope with changing processes: 
"... DAERA now want you to do everything on the computer online ... before, the farm advisor would come out and sit and talk to you. There is no personal contact at all" (Spouse, aged 50+).

"When I started being a farmer in 1982, I can still remember a great Department of Agriculture personnel who helped my farm develop, and if there was a grant application, a bit of guidance to help me, lots of things, they really helped. That person does not exist anymore within the Department" (Farmer 15, aged 50+).

"DAERA needs to go back to its roots and have a more emotional connection with the family farm like it did in the 1980's" (Farmer 9, aged 50+).

The consensus amongst interviewees was that these changes were for the negative, with one successor describing representatives in the government body as 'pencil pushers in their ivory tower' (Successor 13, aged 18-29), who were no longer in touch with the farmer and what the family farm needed. Despite agricultural, and more broadly rural, developments over the last few decades, farming in NI remains fairly traditional, and many of the older farmers felt that they needed personal, and preferably physical, communication with advisors:

"Farming is such a different occupation, and a different business, and it's something you have to visually see and understand, and then you have to be from it as well, I think... 'You would [in the past] have an advisor and they would walk the farm with you, and they had come up with ideas and seeing things through their eyes. But now you just have to apply it all online and there's something seriously missing there" (Farmer 3, aged 50+).

The interviewees' narratives explored how they felt that the government had lost touch with farming families, and as a result has lost respect towards the family farm, despite more positive relationships in the past. These discussions reflected on themes of loss, particularly around their connectedness to the Department, and the emotional security that it had once provided. The farmers and successors interviewed admitted to becoming unengaged with policy advice, which was potentially seriously damaging for farm decision-making support. As Farmer 6 (aged 50+) noted:

"I've been at a few of these seminars, these retirement successions, and these farmers come along and they're lovely - the best of the world - and they have fear, and you could see them 'cause I' $m$ looking from the outside looking in, and you can see they're scared, but when they leave the room, they don't take anything with them."

\section{Conclusions and Implications}

This research set out to pay attention to the emotional aspects of farming decision making around retirement and succession. Drawing on a series of in-depth oral life history interviews with farmers, their spouses, and successors, this article explored how family farm participants' emotions towards place, and their sense of place belonging, influences family farm decision-making processes [9].

The interviews revealed how farmers, and their families, depend on their surroundings and farm relationships (explored broadly, including family, animals, place, and policy makers) to understand their emotional and physical identities, but felt that these identities were being threatened. The farmers had a strong sense of place belonging in their farmland, because it is here where most participants spent most of their time, where they physically worked their land, and where social and familial bonds were made and strengthened. It also became clear through the participants' narratives that there was enduring emotional security and comfort gained from generations of family on the land, where a consequent 'pride of place' was forged. However, this passion and reliance on the traditional family farm were often subject to a push-pull dynamic. Alongside this pride, there was a changing tide towards more pragmatic views of responsibilities towards retaining the family name on the farm. This was evident across all cohorts (farmers, spouses, and successors); the interviews revealed anxieties around not wanting to pass on a 'poisoned chalice', and 
explored generational work ethic differences. Yet, these changing attitudes were not always shared, and there were cases where a 'longing for belonging', and its relationship with the survival of the farm, and farming name, created conflict between farmers and successors. Despite significant agricultural or rural developments, attachment to the land and the desire to keep the farm in the family, remained persistent. This longing for belonging was multipronged and complex, and the emotional aspects of these preferences, and often pressures, revealed the intergenerational and gendered relations involved in retirement decision making. From a policy perspective, the discussions with farmers and their families strongly suggested that a greater understanding of the emotional aspects of farming decision making could act to rebuild relationships between the government department responsible for rural affairs and farming communities. Our work with farming families suggested that further research is needed on the links between the emotional impacts of decision making in family farming and the health and well-being of farming families, particularly in order to encourage rural sustainability.

An innovative 'Work and Talk' oral life history methodology provided greater insights into the important relationship dynamics on the family farm, through first-hand observation of family farm roles. This participatory approach highlighted, through the embodiment of working and talking (see Riley in relation to walking and talking [61-64], the methodological advantages of encouraging participants to recollect by linking place-their farm - through time and their emotional experiences. This research has advocated for a greater appreciation of the emotional aspects of family farming, which are often overlooked at the expense of economic factors. By explicitly paying attention to the emotions of farming families, the interviews revealed the emotional social activities and individual emotional securities built through a sense of place belonging and how these can benefit (e.g., through enhanced support) or challenge (e.g., through additional pressures) family farm decision making. The findings resonate with Conway et al.'s claim that it is the 'soft' issues in family farming that are the 'hard' issues affecting retirement and succession decision making [81]. By focusing specifically on the relationships between place belonging and the challenges faced by farmers in deciding to 'let go' of the family farm, and/or to retire, our analysis contributes to an emerging body of rural research which aims to explore emotions across a diversity of issues impacting family farm decision-making processes.

Author Contributions: Conceptualisation, L.A.H., G.C. and A.S.; methodology, L.A.H., G.C., R.N. and A.S.; formal analysis, L.A.H.; writing, review and editing, L.A.H., G.C., R.N. and A.S.; Supervision, G.C., R.N. and A.S. All authors contributed to writing, editing and reviewing the draft submitted. All authors have read and agreed to the published version of the manuscript.

Funding: This research was funded by the Department of Agriculture, Environment and Rural Affairs (DAERA) as a Ph.D. scholarship awarded to Lorraine Holloway in September 2016, mail to: karen.patterson@daera-ni.gov.uk.

Institutional Review Board Statement: The study was conducted according to the guidelines of the Declaration of Helsinki, and approved by the Institutional Review Ethics Committee at Queen's University Belfast (EPS 19-250 updated on 1 June 2020).

Informed Consent Statement: Informed consent was obtained from all participants involved in this study.

Data Availability Statement: The data are not publicly available for confidentiality reasons and in line with ethical considerations.

Acknowledgments: The authors are grateful to the Department of Agricultural and Rural Affairs (DAERA) for funding and advice. Sincere thanks to the guest editor John McDonagh for preparing this Special Issue. Thank you to the anonymous peer reviewers, for their valuable feedback on previous drafts and Linda Price's generous support with the initial stages of this project. Lastly, we would like to pay our gratitude and respect to our dear co-author and colleague, Aileen Stockdale, who passed away suddenly in March 2021. Aileen was instrumental in the creation of this research project and championed it until the end with great enthusiasm and valuable direction. Aileen was not only an outstanding academic in her field, but she was also a dear friend to many who was 
always generous with her time (and great sense of humour). Aileen was constantly in our thoughts for this Special Issue and will be forever missed but not forgotten.

Conflicts of Interest: The authors declare no conflict of interest.

Appendix A. Sample Interview Question Guide

\section{Farming Background:}

How long have you been in your role as farmer/successor/spouse?

Are you satisfied with your role?

Did you grow up on a farm?

If yes, level of involvement on farm?

If no, what were your previous experiences of farming?

How did you acquire the farm/role? (bought/inherit/marriage/succession) Were you involved in this decision?

If inherited, how many generations of your family has farmed this land?

Did you want the role?

If no, what did you want to do?

What influenced your decision to then farm?

Is farming your only job? (FT/PT/Hobby)

If no, what is your other job?

What influenced(s) this decision?

Do you think farming as a 'way of life' has changed over your life-course?

Do you think it is important to keep the farm in the family? (patrilineal)

How?

Why? Has this opinion changed?

\section{Family Farm Decision Making:}

How are farm decisions made and communicated on the family farm?

Who do you think is the principal decision-maker on the farm?

How involved are you in the farm decision-making process?

Do you discuss farm issues as a family?

Would you like more say in the decision-making process?

Has the farm decision-making process changed over the years?

\section{Succession Decision Making:}

What have been the main influences on succession decision-making in your farm household to date?

Are there any (other) external/internal influences?

Is there anything you would like to change about how succession decision-making is communicated/decided in your farm household?

Who do you think is the lead farmer-older farmer or successor?

If not you, do you want to be? And what do you think the challenges are to accomplish tthis?

What are your challenges and fears for the family farm?

\section{Retirement Decision Making:}

They say farmers don't retire-do you agree with this statement?

What have been the main influences on retirement decision-making in your farm household to date?

Have there been any (other) external/internal influences?

How has this changed over your life-course?

What is your role in the retirement decision-making process?

How are these retirement decisions communicated within the family?

As successor, do you have any say in the retirement decision-making process? e.g., when you take over the farm officially. If not, would you/how?

Do you think farm retirement decision-making is more emotional for farm families than any other occupation?

Farming Identity \& Sense of Belonging in Place:

How do you see yourself as a 'farmer'/spouse? (i.e., caretaker of the land). Has this changed in your lifetime?

Do you think the farming identity has changed? (any change in roles, values?)

What do you think are the main values of a farmer? Has this changed?

How attached are you as farmer to the farm today? Has/how has this changed in your lifetime?

How attached are you to the livestock/nature on the farm? Does this attachment affect your decision to retire/succeed?

Is your home a form of attachment to your role as farmer/successor/spouse?

If you do stay in the family home, is it important to still have a role on the family farm? 


\footnotetext{
If you can't stay in the family home, what will you do?

Do you think to remain living on the farm in retirement is a good way to ease the transition out of farming? Does it help with the stress of retiring?
}

\section{A Sense of Belonging in Rural Communities:}

Do you agree with the statement that the family farm is the heart of rural communities today? Why and has this changed in your life-course/how?

Do you feel part of your local community? Has this changed over the years/why?

Do you think the farm reflects who you are in your rural community, networks, relationships? Is this important and has this

changed over your life-course?

Do you socialise in your community/how?

What other clubs/networks/unions ave you been part of, if any? How often did you meet and is this important to you? Has this changed over your life-course?

If you do not socialise, what do you do? Has this changed? How does this make you feel?

How do you feel about rural communities today?

Do you think rural communities have changed? Do you think this affects your decision to retire or stay on the farm?

Do you think traditional family farms have kept up with modern rural communities?

Is there anything you think that would help farmers integrate better into changing rural communities?

\section{Retirement/Succession Policies:}

How do current rural development policies help/encourage you as a farmer in the retirement/succession process? How has this changed in your life-course?

Are you aware of all current policies to support retirement/succession? How are they communicated to you (if any)? Your views on the success of these policies?

Have there been any policies in your lifetime that you think helped the retirement/succession process?

How do you think the government might help farmers through retirement/succession planning and encourage younger farmers back into the farming industry?

What support do you think is needed for a smoother retirement/succession on the farm?

Are there any other issues with rural development policies or the retirement and succession decision making process that you would like to discuss?

\section{References}

1. Lowder, S.K.; Sánchez, M.V.; Bertini, R. Farms, Family Farms, Farmland Distribution and Farm Labour: What Do We Know Today? Food and Agriculture Organization of the United Nations FAO: Rome, Italy. Available online: https://www.fao.org/3/ca703 6en/ca7036en.pdf (accessed on 2 November 2021).

2. Agricultural Survey. Available online: https://www.daera-ni.gov.uk/sites/default/files/publications/daera/Results\%20of $\% 20$ the\%20December\%202018\%20Agricultural\%20Survey.pdf (accessed on 20 June 2020).

3. Farming in Northern Ireland; Ulster Farmers Union: Belfast, UK. Available online: https:/ /www.ufuni.org/farming (accessed on 2 November 2021).

4. Calus, M.; Huylenbroeck, G. The persistence of family farming: A review of explanatory socio-economic and historical factors. J. Comp. Fam. Stud. 2010, 41, 639-660. [CrossRef]

5. EU Farm Structure Survey. Available online: https://www.daera-ni.gov.uk/articles/eu-farm-structure-survey (accessed on 3 November 2021).

6. Succession Planning in Northern Ireland Report, A Survey of Farmers Plans and Intentions.; Ulster Farmers Union: Belfast, UK; Available online: https:/ / content17.green17creative.com/media/99/files/SUCCESSION-ARTWORK-DOUBLE-PAGES_webfinal_2.pdf (accessed on 1 November 2017).

7. Bryant., L.; Garnham., G. The fallen hero: Masculinity, shame and farmer suicide in Australia. Gend. Place Cult. 2015, $22,67-82$. Available online: https:/ / www.tandfonline.com/doi/abs/10.1080/0966369X.2013.855628 (accessed on 2 March 2018). [CrossRef]

8. Errington, A.; Gasson, R. Labour use in the farm family business. Sociol. Rural. 1994, 34, 293-307. [CrossRef]

9. Rieple, A.; Snijders, S. The role of emotions in the choice to adopt, or resist, innovations by Irish dairy farmers. J. Bus. Res. 2018, 85, 23-31. [CrossRef]

10. Antonsich, M. Searching for belonging-An analytical framework. Geogr. Compass 2010, 4, 644-659. [CrossRef]

11. Wood, N.; Smith, S.J. Instrumental routes to emotional geographies. Soc. Cult. Geogr. 2004, 5, 533-548. [CrossRef]

12. Simonsen, K. Practice, Spatiality and Embodied Emotions: An Outline of a Geography of Practice. Hum. Aff. 2007, 17, 168-181. [CrossRef]

13. Van der Veen, M. Agricultural innovation: Invention and asoption or change and adaption? Word Archaeol. 2010, 42, 1-12. [CrossRef]

14. Anderson, K.; Smith, S. Editorial: Emotional geographies. Trans. Inst. Br. Geogr. 2001, 26, 710. [CrossRef]

15. Pini, B.; Mayes, R.; McDonald, P. The emotional geography of a mine closure: A study of the Ravensthorpe nickel mine in Western Australia. Soc. Cult. Geogr. 2010, 11, 559-574. [CrossRef] 
16. Ramirez-Ferroro, E. Troubled Fields, Men, Emotions and the Crisis in American Farming; Columbia University Press: New York, NY, USA, 2015.

17. Price, L.; Conn, R. 'Keeping the Name on the Land': Patrilineal Succession in Northern Irish Family Farming. Keeping It in the Family, International Perspectives on Succession E Retirement on Family Farms; Lobely, M., Baker, J., Eds.; Ashgate Publishing Ltd.: Surrey, UK, 2012.

18. Conway, S.F.; Mcdonagh, J.; Farrell, M.; Kinsella, A. Cease agricultural activity forever? Underestimating the importance of symbolic capital. J. Rural Stud. 2016, 44, 164-176. [CrossRef]

19. Conway, S.F.; McDonagh, J.; Farrell, M.; Kinsella, A. Uncovering obstacles: The exercise of symbolic power in the complex arena of intergenerational family farm transfer. J. Rural Stud. 2017, 54, 60-75. [CrossRef]

20. Glover, F.; Reay, T. Sustaining the family business with minimal financial rewards: How do family farms continue? Fam. Bus. Rev. 2013, 28, 163-177. [CrossRef]

21. Grubbstrom, A.; Eriksson, C. Retired farmers and new land users: How relations to land and people influence farmers' land transfer decisions. Sociol. Rural. 2018, 58, 707-725. [CrossRef]

22. Shamai, S. Sense of place: An empirical measurement. Geoforum 1991, 22, 347-358. [CrossRef]

23. Buffel, T.; De Donder, L.; Philipson, C.; De Witte, N.; Dury, S.; Verte, D. Place attachment among older adults living in four communities in Flanders, Belgium. Hous. Stud. 2014, 29, 800-822. [CrossRef]

24. Longhurst, R. Introduction: Subjectivities, spaces and places. In Handbook of Cultural Geography; Anderson, K., Domosh, M., Pile, S., Thrift, N., Eds.; Sage: London, UK, 2003; pp. 283-289.

25. Stockdale, A.; Theunissen, N.; Haartsen, T. Staying in a state of flux: A life course perspective on the diverse staying processes of rural young adults. Popul. Space Place 2018, 24, e2139. [CrossRef]

26. Erickson, L.D.; Sanders, S.R.; Cope, M.R. Lifetime stayers in urban, rural, and highly rural communities in Montana. Popul. Space Place 2018, 24, e2133. [CrossRef]

27. Stockdale, A.; Ferguson, S. Planning to stay in the countryside: The insider-advantages of young adults from farm families. J. Rural Stud. 2020, 78, 364-371. [CrossRef]

28. Ryan, K. Incorporating emotional geography into climate change research: A case study in Londonderry, Vermont, USA. Emot. Sp. Soc. 2016, 19, 5-12. [CrossRef]

29. Wright, S. More-than-human, emergent belongings: A weak theory approach. Prog. Hum. Geogr. 2015, 39, 391-411. [CrossRef]

30. Allen, K.-A.; Kern, M.L. The need to belong. In School Belongings in Adolescents; Allen, K.-A., Kern, M.L., Eds.; Springer: Singapore, 2017; pp. 5-12.

31. Bryant, L.; Pini, B. Gender and Rurality; Routledge: New York, NY, USA; London, UK, 2011.

32. Allen, K.-A.; Kern, M.L.; Rozek, C.S.; McInerney, D.M.; Slavich, G.M. Belonging: A review of conceptual issues, an integrative framework, and directions for future research. Aust. J. Psychol. 2021, 73, 87-102. [CrossRef] [PubMed]

33. Hendry, L.B.; Mayer, P.; Kloep, M. Belonging or opposing? A grounded theory approach to young people's cultural identity in a majority/minority societal context. Identit. Int. J. Theory Res. 2007, 7, 181-204. [CrossRef]

34. Fenton, E.; Shields, C.; Mcginn, K.; Manley-Casimir, M. Exploring Emotional Experiences of Belonging. Workplace 2012, 19, 40-52.

35. Price, L.; Evans, N. From stress to distress: Conceptualizing the British family farming patriarchal way of life. J. Rural Stud. 2009, 25, 1-11. [CrossRef]

36. Riley, M. 'Letting them go'-Agricultural retirement and human-livestock relations. Geoforum 2011, 42, 16-27. [CrossRef]

37. Riley, M. Silent Meadows: The uncertain decline and conservation of hay meadows in the British landscape. Landsc. Res. 2005, 30, 437-458. [CrossRef]

38. Agricultural Census Northern Ireland. 2009. Available online: https://www.daera-ni.gov.uk/publications/agricultural-censusnorthern-ireland-2019 (accessed on 22 April 2020).

39. Agricultural Census Northern Ireland. 2020. Available online: https://www.daera-ni.gov.uk/news/final-results-juneagricultural-census-2020 (accessed on 1 November 2021).

40. Brexit: Future UK Agriculture Policy. 2018. Available online: https://www.parliament.uk/documents/commons-library/BrexitUK-agriculture-policy-CBP-8218.pdf (accessed on 7 July 2020).

41. Brexit and Agriculture in Northern Ireland, House of Commons, Northern Ireland Affairs Committee, Fifth Report of Session 2017-2019, House of Commons, HC 939. Available online: https:/ / publications.parliament.uk/pa/cm201719/cmselect/cmniaf/ 1847/184702.htm (accessed on 1 November 2021).

42. Price, L.; Simpson, M. The trouble with accessing the countryside in Northern Ireland. Environ. Law Rev. 2017, 19, 183-200. [CrossRef]

43. A History of Land Tenure Arrangements in Northern Ireland, University of Maine. Available online: http:/ / dlc.dlib.indiana. edu/dlc/bitstream/handle/10535/4180/A_History.pdf?sequence=1 (accessed on 14 March 2020).

44. Feehan, J. Farming in Ireland, History, Heritage and Environment; University College Dublin: Dublin, Ireland, 2003.

45. Charmaz, K. Grounded Theory. In Contemporary Field Research; Emerson, R.M., Ed.; Waveland Press, Inc.: Long Grove, IL, USA, 2001; pp. 335-352.

46. Charmaz, K. Constructing Grounded Theory: A Practical Guide through Qualitative Analysis; Sage: Thousand Oaks, CA, USA, 2006.

47. Creswell, J.; Path, C. Qualitative Inquiry and Research Design, Choosing Among Five Approaches, 4th ed.; SAGE: London, UK, 2018. 
48. December Agricultural Survey 2018. Available online: https://www.daera-ni.gov.uk/publications/december-agriculturalsurvey-2018 (accessed on 12 November 2017).

49. Burton, R.J. Seeing through the 'good farmer's' eyes: Towards developing an understanding of the social symbolic value of 'productivist' behaviour. Sociol. Rural. 2004, 44, 195-215. [CrossRef]

50. Statistical Review of Northern Ireland Agriculture 2019. Available online: https://www.daera-ni.gov.uk/sites/default/files/ publications / daera/Stats\%20Review\%202019\%20final.pdf. (accessed on 7 July 2021).

51. Registrar General Northern Ireland Annual Report 2016. Available online: https://www.nisra.gov.uk/sites/nisra.gov.uk/files/ publications/RG2016.pdf (accessed on 27 March 2019).

52. Rosefield, R. US farm women: Their part in farm work and decision making. Work Occup. 1986, 13, 179-202. [CrossRef]

53. Garner, E.; De La, O.; Campos, A. Identifying The "Family. Farm": An Informal Discussion of the Concepts and Definitions; ESA Working Paper No. 14-10; FAO: Rome, Italy, 2014.

54. Chiswell, H.M. The importance of next generation farmers: A conceptual framework to bring the potential successor into focus. Geogr. Compass 2014, 8, 300-312. [CrossRef]

55. Cassidy, A.; McGrath, B. The relationship between 'non-successor' farm offspring and the continuity of the Irish family farm. Sociol. Rural. 2014, 54, 399-416. [CrossRef]

56. Ghaljaie, F.; Naderifar, M. Snowball sampling A purposeful method of sampling in qualitative research. Strides Dev. Med. Educ. 2017, 4, 1-4. [CrossRef]

57. Price, L. The Women's Land Army and Geographies of Gender Identity: Remembering the Impact. In Proceedings of the Association of American Geographers Annual Conference, New York, NY, USA, 1-2 February 2012; pp. 1-3. Available online: https:/ / pure.qub.ac.uk/en/publications/the-womens-land-army-and-geographies-of-gender-identity-rememberi (accessed on 3 November 2021).

58. Alston, M. Gender-based-violence in post-disaster recovery situations: An emerging public health issue. In Gender Based Violence and Its Impact on Health; Nakray, K., Ed.; Routledge: Oxfordshire, UK, 2012.

59. Weeks, J. Telling stories about men. Sociol. Rev. 1996, 44, 746-756. [CrossRef]

60. Anderson, J. Talking whilst walking: A geographical archaeology of knowledge. AREA 2004, 36, 254-261. [CrossRef]

61. Riley, M.; Harvey, D. Place-Based Interviewing: Creating and Conducting Walking Interviews; SAGE Publications: London, UK, 2016; Available online: http:/ / www.doi.org/10.4135/978144627303015595386 (accessed on 10 November 2021).

62. Riley, M. Bringing the 'invisible farmer' into sharper focus: Gender relations and agricultural practices in the Peak District (UK). Gend. Place Cult. 2009, 16, 665-682. [CrossRef]

63. Riley, M. Experts in Their Fields: Farmer - Expert Knowledges and Environmentally Friendly Farming Practices. Environ. Plan A. 2008, 40, 1277-1293. [CrossRef]

64. Riley, M. Ask the Fellows Who Cut the Hay: Farm Practices, Oral History and Nature Conservation. Oral Hist. 2004, $32,45-53$.

65. Evans, J.; Jones, P. The walking interview: Methodology, mobility and place. Appl. Geogr. 2011, 31, 849-858. [CrossRef]

66. Riley, M. Emplacing the research encounter: Exploring farm life histories. Qual. Inq. 2010, 16, 651-662. [CrossRef]

67. Kuehne, G. Eight issues to think about when interviewing farmers. Forum Qual. Social. I Forum Qual. Soc. Res. 2016, 17, 20.

68. Brown, E.; Gray, R.; Monaco, S.L.; O'Donoghue, B.; Nelson, B.; Thompson, A.; Francey, S.; McGorry, P. The potential impact of COVID-19 a psychosis: A rapid review of contemporary epidemic pandemic research. Schizophr. Res. 2020, 222, 79-87. [CrossRef]

69. Lolacono, V.; Brown, P.M. Skype as a tool for qualitative research interviews. Sociol. Res. Online 2016, 21, 103-117. [CrossRef]

70. Mealer, M.; Jones, J. Methodological and ethical issues related to qualitative telephone interviews on sensitive topics. Nurse Res. 2018, 21, 32-37. [CrossRef] [PubMed]

71. Deaken, H.; Wakefield, K. Skype interviewing: Reflections of two PhD researchers. Qual. Res. 2013, 14, 603-616. [CrossRef]

72. Ajzen, I. The theory of planned behavior. Organ. Hum. Behav. Dec. Proc. 1991, 50, 121-179. [CrossRef]

73. Fenster, T. The right to the gendered city: Different formations of belonging in everyday life. J. Gend. Stud. 2005, 14, 217-231. [CrossRef]

74. Yuval-Davis, N. Belonging and the politics of belonging: Intersectional contestations. Sociology 2015, 49, 1-2. [CrossRef]

75. Maliene, V.; Dixon-Gough, R.; Malys, N. Dispersion of narrative importance values contributes to the ranking uncertainty. Appl. Softw. Comput. 2018, 67, 286-298. [CrossRef]

76. Gasson, R.; Errington, A. The Family Farm Business; CAB International: Wallingford, UK, 1993.

77. Tovey, H. Risk, morality and the sociology of animals-Reflections on the foot and mouth outbreak in Ireland. Irel. J. Sociol. 2002, 11, 23-42. [CrossRef]

78. Bock, B.; van Huik, M.; Prutzer, M.; Kling Eveillard, F.K.; Dockes, A. Farmers' relationship with different animals: The importance of getting close to the animals. Case studies of French, Swedish and Dutch cattle, pig and poultry farmers. Int. J. Sociol. Food Agric. 2007, 15, 108-125.

79. Riley, M. Still Being the 'Good Farmer': (Non-)retirement and the Preservation of Farming Identities in Older Age. Sociologia Ruralis 2016, 56, 96-115. [CrossRef]

80. DAERA. Available from: About DAERA Department of Agriculture, Environment and Rural Affairs (daera-ni.gov.uk). Available online: http: / / www.daera-ni.gov.uk/ (accessed on 28 November 2020).

81. Conway, S.F.; McDonagh, J.; Farrell, M.; Kinsella, A. Till death do us part: Exploring the Irish farmer-farm relationship in later life through the lens of 'Insideness'. Int. J. Agric. Manag. 2018, 7, 1-13. 